\title{
Pengaruh DER, ROA, SIZE, EPS, cash position dan TATO terhadap DPR perusahaan manufaktur Periode 2016-2019
}

\section{Qori Nurul Hasanah Harahap*;Monika Br Situmorang; Fristalia Karina Br Karo; Keumala Hayati}

\author{
Prodi Akuntansi, Fakultas Ekonomi, Universitas Prima Indonesia, Medan \\ *E-mail korespondensi: qorihrp4@gmail.com
}

\begin{abstract}
The purpose of this study is to examine the effect of DER, ROA, Firm Size, EPS, Cash Position, and Total Asset Turnover using the t-test and F test. This study uses quantitative descriptive. The number of manufacturing companies used as a population is 169 companies selected based on purposive sampling obtained a sample of 54 companies. The data analysis technique used is multiple linear regression analysis. The results of data analysis partially show that only DER has a significant negative impact on DPR. Simultaneously, six independent variables have a substantial effect on the $D P R$. The coefficient of determination test results shows the Adjusted $R$ Square number of 0.108 , which means $10.8 \%$ of the variation from the DPR of manufacturing companies, which can be explained by the independent variables used. The remaining $89.2 \%$ is caused by other factors such as Growth Opportunity, Ownership, Current Ratio, and others.
\end{abstract}

Keywords: DER, ROA, Firm Size, EPS, Cash position, TATO, DPR

\begin{abstract}
Abstrak
Tujuan dari penelitian ini yaitu untuk mengkaji pengaruh DER, ROA, firm size, EPS, cash position dan total asset turnover menggunakan uji t dan uji F. Penelitian ini menggunakan deskriptif kuantitatif. Jumlah perusahaan manufaktur yang dijadikan populasi yaitu sebanyak 169 perusahaan yang dipilih berdasarkan sampling purposive diperoleh sampel sebanyak 54 perusahaan. Teknik analisis data yang digunakan adalah analisis regresi linear berganda. Hasil analisis data menunjukkan secara parsial hanya DER berdampak negatif signifikan terhadap DPR. Secara bersamaan enam variabel independen berdampak signifikan terhadap DPR. Hasil uji koefisien determinasi menunjukkan angka adjusted $R$ square 0,108 yang artinya sebesar 10,8\% variasi dari DPR perusahaan manufaktur yang dapat dijelaskan oleh variabel bebas yang digunakan selebihnya $89,2 \%$ disebabkan oleh faktor lainnya seperti growth opportunity, ownership, current ratio dan lain-lain.
\end{abstract}

Kata kunci: DER, ROA, Firm Size, EPS, Cash position, TATO, DPR.

\section{PENDAHULUAN}

Perusahaan manufaktur terbagi menjadi beberapa jenis perusahaan yang bergerak dalam berbagai bidang seperti industri dasar dan kimia, aneka industri dan aneka barang konsumsi. Saham perusahaan manufaktur lebih banyak diminati oleh investor karena skala produksinya cukup besar dan memiliki pangsa pasar yang luas. di Indonesia terdapat banyak sekali perusahaan manufaktur, tercatat 169 perusahaan manufaktur yang listing di Bursa Efek Indonesia.

Permasalahan tentang pembagian dividen menarik untuk diteliti karena di satu sisi perusahaan mengharapkan adanya pertumbuhan secara terus menerus untuk 
mempertahankan kelangsungan hidup perusahaan sedang di sisi lain dividen sangat penting untuk memenuhi harapan pemegang saham terhadap tingkat pengembalian investasinya. Semakin besar dividen kas yang dibayarkan oleh perusahaan, maka semakin besar pula pendanaan eksternal yang dibutuhkan melalui pinjaman hutang atau penjualan saham. Ada beberapa faktor yang mempengaruhi rasio pembayaran dividen seperti debt to equity ratio, return on asset, firm size, earning per share, cash position dan total asset turnover.

Penelitian sebelumnya oleh Fitriati (2018) menunjukkan firm size dan DER berpengaruh positif signifikan terhadap DPR sedangkan ROE, Current Ratio dan Institusional Ownership tidak berpengaruh terhadap DPR. Penelitian lainnya oleh Wahyuni dan Hafiz (2018), menunjukkan CR tidak berpengaruh terhadap DPR, DER berpengaruh negatif signifikan terhadap DPR dan ROA berpengaruh positif signifikan terhadap DPR. Ada juga penelitian Angeline (2019) yang menunjukkan hanya ROA yang berpengaruh terhadap DPR sedangkan CR, DER dan TATO tidak berpengaruh terhadap DPR.

Debt to equity ratio menunjukkan tingkat penggunaan hutang oleh suatu perusahaan yang dilihat dari posisi modalnya. Semakin tinggi penggunaan hutang maka akan semakin kecil modal pemilik, pada umumnya investor cenderung berhati-hati dalam memilih perusahaan yang memiliki rasio DER yang tinggi karena penggunaan hutang yang tinggi berisiko tinggi pada dana yang diinvestasikan oleh investor yang nantinya akan berdampak pada pembagian dividennya. Dengan kata lain perusahaan yang memiliki tingkat hutang yang tinggi cenderung untuk mengurangi jatah pembagian dividen kepada pemegang saham untuk keperluan pembayaran hutangnya.

Return on Asset merupakan salah satu rasio profitabilitas. Perolehan laba sangatlah penting karena perusahaan akan membagikan dividen jika perusahaan mendapatkan laba. Namun dapat dilihat pada industri manufaktur cukup banyak perusahaan yang mengalami kerugian sekitar 51 perusahaan, menyebabkan perusahaan tidak dapat membayar dividen kepada pemegang saham.

Firm size menunjukkan skala perusahaan tersebut, jika semakin besar size suatu perusahaan tentu memiliki aset yang besar pula, aset tersebut dapat dijadikan jaminan kepada investor karena dengan aset yang besar perusahaan mampu mengembangkan bisnisnya dengan baik dan meraup keuntungan yang lebih besar pula.

Earning per share menunjukkan keuntungan dari setiap lebar saham yang dimiliki oleh pemegang saham, semakin besar EPS menunjukkan semakin tingginya earning/pendapatan perusahaan yang menunjukkan kesanggupan perusahaan dalam membayarkan dividennya. Namun jika semakin banyak saham yang dilepas oleh perusahaan tentunya akan mengurangi tingkat laba yang akan dimiliki oleh pemegang saham.

Cash position suatu perusahaan sangat penting untuk dianalisis karena dividen merupakan kas keluar sehingga jika perusahaan tidak memiliki posisi kas yang baik maka dapat mengganggu pembagian dividennya.

Total aset turnover digunakan untuk mengukur kemampuan perusahaan dalam menghasilan penjualan dengan menggunakan aset yang ada. Seperti diketahui perusahaan manufaktur memiliki aset yang cukup besar untuk mendukung kegiatan produksinya sehingga dengan menganalisis perputaran asetnya investor dapat mengetahui efektivitas manajemen dalam meningkatkan penjualannya. Jika penjualan meningkat tentu akan berdampak pada perolehan laba dan dividen yang dibagikan juga akan stabil.

Beberapa research gap yang ada selama ini yaitu pada penelitian Angeline (2019) secara parsial hanya ROA yang memiliki pengaruh terhadap dividend payout ratio, sedangkan tiga variabel lainnya: current ratio, DER dan total asset turnover 
tidak berpengaruh terhadap dividend payout ratio. Penelitian lain oleh Safrianto (2017) secara parsial cash position dan ROA berpengaruh signifikan positif sedangkan DER tidak berpengaruh terhadap DPR.

Peneliti tertarik untuk meneliti pada perusahaan manufaktur yang disebabkan adanya fenomena yang terjadi yang bertolak belakang dengan hasil penelitian terdahulu.

Tabel 1.Fenomena penelitian

\begin{tabular}{llrrrr}
\hline Kode & Variabel & $\mathbf{2 0 1 6}$ & $\mathbf{2 0 1 7}$ & $\mathbf{2 0 1 8}$ & $\mathbf{2 0 1 9}$ \\
\hline INTP & Hutang & 4.011 .877 & 4.307 .169 & 4.566 .973 & 4.627 .488 \\
& Laba Bersih & 3.870 .319 & 1.859 .818 & 1.145 .937 & 1.835 .305 \\
& Aset & 30.150 .580 & 28.863 .676 & 27.788 .562 & 27.707 .749 \\
& Jumlah Saham & 3.681 .231 .699 & 3.681 .231 .699 & 3.681 .231 .699 & 3.681 .231 .699 \\
& Kas & 9.674 .030 & 8.294 .891 & 7.225 .876 & 7.651 .750 \\
& Penjualan & 15.361 .894 & 14.431 .211 & 15.190 .283 & 15.939 .348 \\
& Dividen & 1.527 .247 & 3.418 .759 & 2.576 .024 & 2.024 .015 \\
\hline SMBR & Hutang & 1.248 .119 .294 & 1.647 .477 .388 & 2.064 .408 .447 & 2.088 .977 .112 \\
& Laba Bersih & 259.090 .525 & 146.648 .432 & 76.074 .721 & 30.073 .855 \\
& Aset & 4.368 .876 .996 & 5.060 .337 .247 & 5.538 .079 .503 & 5.571 .270 .204 \\
& Jumlah Saham & 9.837 .678 .500 & 9.924 .797 .283 & 9.932 .534 .336 & 9.932 .534 .336 \\
& Kas & 341.602 .275 & 491.035 .415 & 475.836 .496 & 202.343 .331 \\
& Penjualan & 1.522 .808 .093 & 1.551 .524 .990 & 1.995 .807 .528 & 1.999 .516 .771 \\
& Dividen & 88.539 .106 & 64.768 .605 & 36.661 .209 & 18.971 .143 \\
\hline SMGR & Hutang & 13.652 .504 & 18.524 .450 & 18.419 .594 & 45.915 .143 \\
& Laba Bersih & 4.535 .036 & 2.043 .025 & 3.085 .704 & 2.371 .233 \\
& Aset & 44.226 .895 & 48.963 .502 & 51.155 .890 & 79.807 .067 \\
& Jumlah Saham & 5.931 .520 .000 & 5.931 .520 .000 & 5.931 .520 .000 & 5.931 .520 .000 \\
& Kas & 2.834 .444 & 3.637 .760 & 5.245 .731 & 3.950 .448 \\
& Penjualan & 26.134 .306 & 27.813 .664 & 30.687 .626 & 40.368 .107 \\
& Dividen & 1.818 .504 & 1.824 .270 & 837.110 & 1.244 .948 \\
\hline
\end{tabular}

Sumber : Laporan Keuangan 2016-2019

Dari Tabel 1. dapat dilihat fenomena yang mencolok terjadi pada emiten berkode SMBR yaitu PT. Semen Baturaja (Persero), Tbk yang mengalami penurunan pembayaran dividen setiap tahunnya dari Rp 88.539.106,- menjadi Rp 18.971.143,dimana jika dilihat dari penjualan dan aset setiap tahunnya mengalami peningkatan, namun laba bersih perusahaan setiap tahunnya malah mengalami penurunan, yang diduga disebabkan terus ditambahnya penggunaan hutang oleh perusahaan sehingga posisi kas juga semakin berkurang.

Maka dari itu, berdasarkan uraian diatas peneliti tertarik untuk membahas lebih dalam lagi mengenai firm size terhadap devidend payout ratio kemudian membuat penelitian yang berjudul "Pengaruh debt to equity ratio, return on asset, firm size earning pe share, cash position dan total asset turnover terhadap devidend payout ratio"

\section{TINJAUAN PUSTAKA}

Peneliti (Rahayuningtyas, 2014) dalam penelitiannya yang berjudul current ratio( $C R)$, return on equity( $R O E)$, total assets turn over (TATO), debt to equity ratio(DER), dan price earning ratio(PER) terhadap devidend payout ratio pada perusahaan yang listing di BEI pada periode 2009-2011 menunjukkan bahwa DER berpengaruh signifikan terhadap devidend payout ratio. Peneliti (Abdullah, Soedjatmiko, \& Hartati, 2016; Alipudin, 2016; Atmoko, Defung, \& Tricahyadinata, 2018; Pribadi \& Sampurno, 2012) juga berpendapat demikian. 


\section{Pengaruh debt to equity ratio terhadap devidend payout ratio}

Rasio ini dilakukan untuk mengukur seberapa jauh perusahaan dibiayai oleh utang.semakin besar hutang maka akan mempengaruhi besar kecil keuntungan bersih yang tersedia bagi pemegang saham termasuk deviden yang diterima.

Debt to equity ratio memiliki nilai yang tinggi untuk menggambarkan bahwa perusahaan kurang baik dan belum bisa untuk memenuhi hutang jangka panjang sehingga akan berdampak pada perspektif investor untuk melakukan investasi (Erari,2014).

\section{Pengaruh return on asset terhadap devidend payout ratio}

Return on asset mengukur kemampuan perusahaan dalam menghasilkan laba bersih berdasarkan tingkat aset tertentu (Wahyuni \& Hafiz, 2018). Semakin tinggi Return on Asset suatu perusahaan, semakin besar pula tingkat keuntungan yang dicapai oleh perusahaan, sehingga akan menarik minat investor untuk menanamkan modalnya pada perusahaan tersebut. return on asset perlu dipertimbangkan oleh investor dalam berinvestasi saham, karena Return on Asset berperan sebagai indikator efisiensi perusahaan dalam menggunakan aset untuk memperoleh laba (Chasanah,2008; Janifairus et al., 2010; Kartika, 2015; Marlina \& Danica, 2009) mengungkapkan variabel ROA berpengaruh positif terhadap DPR.

\section{Pengaruh firm size terhadap devidend payout ratio}

Ukuran perusahaan menggambarkan skala besar kecilnya perusahaan yang dilihat dari total aktiva perusahaan pada akhir tahun. Suatu perusahaan besar yang sudah mapan akan memiliki akses mudah menuju pasar modal. Kemudahan ini cukup berarti untuk fleksibilitas dan kemampuannya untuk memperoleh dana yang lebih besar, sehingga perusahaan mampu memiliki dividend payout ratio lebih tinggi daripada perusahaankecil. Jadi semakin besar ukuran perusahaan maka dividen yang dibagikan juga semakin besar(Hanif \& Bustaman, 2017).

\section{Pengaruh earning pe share terhadap deviden payout ratio}

EPS yang meningkat menandakan bahwa perusahaan berhasil meningkatkan kemakmuran investor dengan berupa pembagian dividen. Hal ini dapat meningkatkan permintaan investor akan saham yang nantinya akan menyebabkan semakin meningkat pula harga saham perusahaan tersebut. Penelitian yang dilakukan oleh (Wahyuni \& Hafiz, 2016) menemukan bahwa secara parsial Earning Pe Share memiliki pengaruh yang positif signifikan terhadap harga saham. Earning Pe Share menunjukkan berapa rupiah laba yang diterima investor atas setiap lembarsaham.

\section{Pengaruh cash position terhadap dividend payout ratio}

Menurut Safrianto (2017) bagi perusahaan yang memiliki posisi kas yang semakin kuat akan semakin besar kemampuannya untuk membayar dividen. Faktor ini merupakan factor internal yang dapat dikendalikan oleh manajemen sehingga pengaruhnya dapat dirasakan secara langsung bagi kebijakan dividen.

\section{Pengaruh total asset turnover terhadap dividend payout ratio}

Menurut Angeline (2019) apabila aset perusahaan dalam bentuk kas dialokasikan dalam saham maka harga saham tersebut mencerminakn tingkat perputaran aktiva yang dikelola oleh manajemen, jika harga saham mengalami kenaikan, maka biasa diindikasikan manajemen mampu mengelola aktiva secara baik. Akan tetapi apabila harga saham stagnan atau menurun berarti manajemen tidak mampu mengelola aktiva tersebut dengan baik dan bisa berakibat pada kerugian. Oleh karena itu Semakin tinggi TATO, maka semakin tinggi pula DPR yang 
dibagikan kepada pemegang saham. Sebaliknya semakin rendah TATO, maka semakin rendah pula DPR yang dibagian kepada pemegang saham.

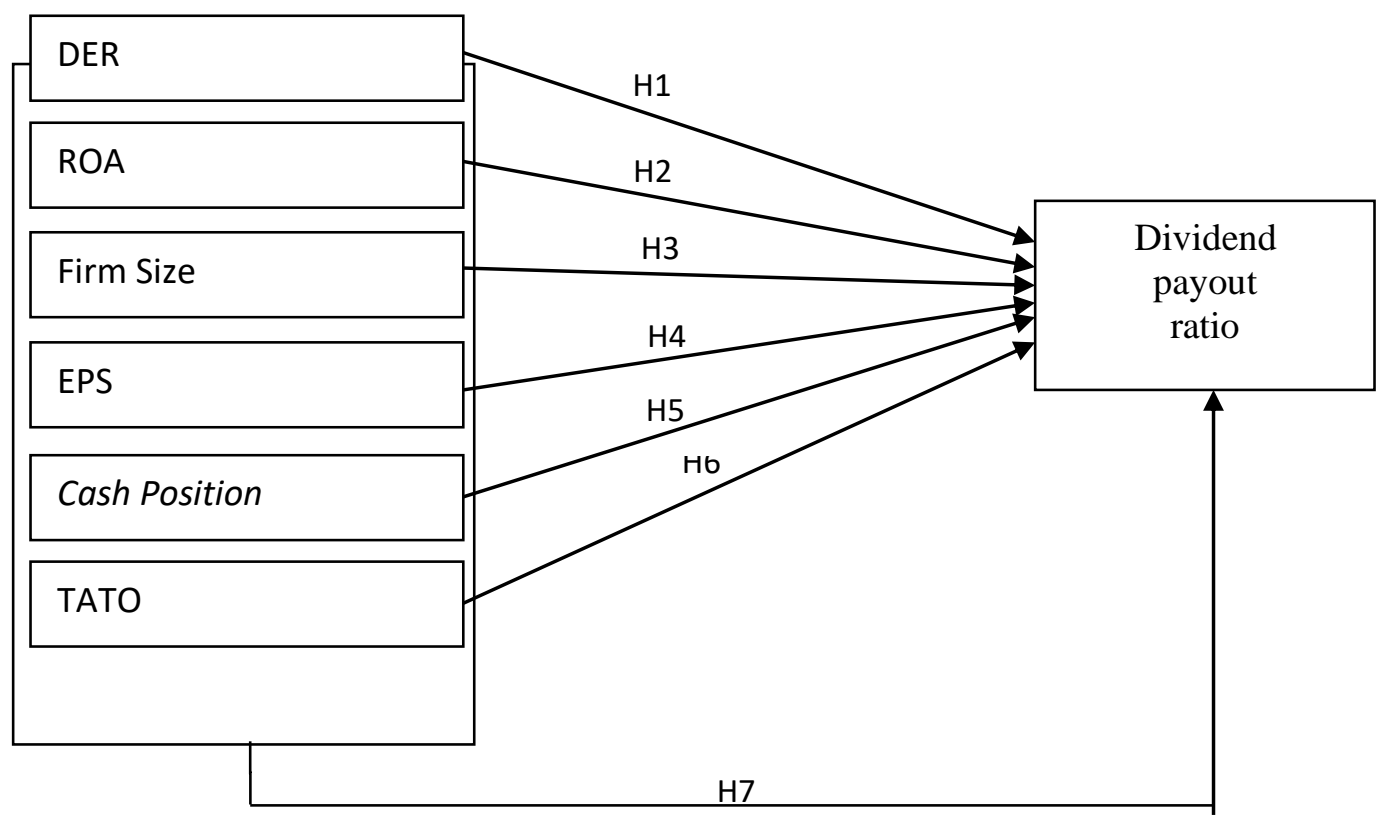

Gambar 1. Kerangka konseptual

\section{Hipotesis}

H1: Debt to equity ratio berpengaruh terhadap devidend payout ratio pada perusahaan manufaktur yang terdaftar di Bursa Efek Indonesia pada periode2016-2019

$\mathrm{H} 2$ : Return on asset berpengaruh terhadap devidend payout ratio padaperusahaan manufaktur yang terdaftar di Bursa Efek Indonesia pada periode2016-2019

H3: Firm size berpengaruh terhadap devidend payout ratio pada perusahaan manufaktur yang terdaftar di Bursa Efek Indonesia pada periode 2016-2019

H4: Earning pe share berpengaruh terhadap devidend payout ratio pada perusahaan manufaktur yang terdaftar di Bursa Efek Indonesia pada periode 2016-2019

H5: Cash position berpengaruh terhadap devidend payout ratio pada perusahaan manufaktur yang terdaftar di Bursa Efek Indonesia pada periode2016-2019

H6: Total asset turnover berpengaruh terhadap devidend payout ratio pada perusahaan manufaktur yang terdaftar di Bursa Efek Indonesia pada periode2016-2019

H7: Debt to equity ratio, return on asset, firm size, earning pe share, cash position dan total asset turnover berpengaruh terhadap devidend payout ratio pada perusahaan manufaktur yang terdaftar di Bursa Efek Indonesia pada periode 2016-2019

\section{METODE}

Metode penelitian merupakan suatu langkah sistematis yang perlu dilewati dalam proses memecahkan berbagai masalah peneliti yang sedang dilakukan, dengan tujuan menghasilkan berbagai penemuan penemuan baru yang bermanfaat bagi masyarakat luas.

\section{Populasi}

Populasi didifenisikan sebagai sekumpulan data yang di klasifikasikan berdasarkan tempat atau lingkup tertentu. Populasi pada penelitian ini berjumlah 169 perusahaan manufaktur yang terdaftar di Bursa Efek Indonesia selama 2016 sampai dengan 2019.

Pemilihan sampel dalam penelitian ini metode purposive sampling yaitu 
metode pemilihan sampel yang dilakukan pada kriteria tertentu dalam memperoleh sampel yang representative terhadap populasi penelitian. Kriteria Pemilihan Sampel sebagai berikut:

Tabel 2. Kriteria pemilihan sampel

\begin{tabular}{clc}
\hline No & \multicolumn{1}{c}{ Kriteria } & Sampel \\
\hline 1 & $\begin{array}{l}\text { Jumlah perusahaan manufaktur yang terdafter di Bursa } \\
\text { Efek Indonesia Periode 2016-2019 }\end{array}$ & 169 \\
2 & $\begin{array}{l}\text { Jumlah perusahaan manufaktur yang delisting atau belum } \\
\text { listing di Periode 2016-2019 }\end{array}$ & $(27)$ \\
3 & $\begin{array}{l}\text { Jumlah perusahaan manufaktur yang tidak memperoleh } \\
\text { keuntungan/ laba pada Periode 2016-2019 } \\
\text { Jumlah perusahaan manufaktur yang tidak melakukan } \\
\text { Pembayaran dividen pada Tahun 2016-2019 }\end{array}$ & $(36)$ \\
\hline & Jumlah sample perusahaan & $\mathbf{5 4}$ \\
\hline & Total observasi (53 x 4) & $\mathbf{2 1 6}$ \\
\hline
\end{tabular}

\section{Identifikasi dan defenisi operasional variabel penelitian} berikut :

Identifikasi dan defenisi operasional penelitian dapat dilihat melalui Tabel 3

Tabel 3. Defenisi operasional dan pengukuran variabel

\begin{tabular}{|c|c|c|c|}
\hline Variabel & Defenisi & Indikator & Skala \\
\hline $\begin{array}{l}\text { Debt to } \\
\text { equity ratio } \\
\left(\mathrm{X}_{1}\right)\end{array}$ & $\begin{array}{l}\text { DER dalam memenuhi seluruh } \\
\text { kewajibannya berapa bagian modal sendiri } \\
\text { dipakai membayar hutang semakin rendah } \\
\text { rasio DER semakin tinggi kemampuan } \\
\text { perusahaan membayar semua kewajibannya } \\
\text { (Mulyawan, n.d.) }\end{array}$ & $\begin{array}{l}\text { DER }=\text { Total } \\
\text { Liability/Total Equity }\end{array}$ & Ratio \\
\hline $\begin{array}{l}\text { Return on } \\
\text { asset } \\
\left(\mathrm{X}_{2}\right)\end{array}$ & $\begin{array}{l}\text { Return on asset merupakan rasio mengukur } \\
\text { kemampuan perusahaan menghasilkan laba } \\
\text { bersih berdasarkan tingkat asset yang } \\
\text { tertentu (Harmono, 2011) }\end{array}$ & $\begin{array}{l}\text { ROA=Earning after } \\
\text { tax/total asset }\end{array}$ & Ratio \\
\hline $\begin{array}{l}\text { Firm size } \\
\left(\mathrm{X}_{3}\right)\end{array}$ & $\begin{array}{l}\text { Firm size merupakan menggambarkan skala } \\
\text { besar kecilnya perusahaan ditentukan oleh } \\
\text { total penjualan, total aktiva dan rata-rata } \\
\text { penjualan perusahaan (Fahmi, 2011) }\end{array}$ & Ln (total aset) & Nominal \\
\hline $\begin{array}{l}\text { Earning per } \\
\text { share }\left(\mathrm{X}_{4}\right)\end{array}$ & $\begin{array}{l}\text { Earning pe } \\
\text { digunakan merupakan ratio yang } \\
\text { perusahaan menghasilkan laba (Fahmi, } \\
\text { 2011) }\end{array}$ & $\begin{array}{l}\text { EPS= Laba } \\
\text { bersih/jumlah saham } \\
\text { beredar }\end{array}$ & Ratio \\
\hline $\begin{array}{l}\text { Cash } \\
\text { position } \\
\left(\mathrm{X}_{5}\right)\end{array}$ & $\begin{array}{l}\text { Cash Position merupakan jumlah kas yang } \\
\text { dimiliki perusahaan dalam suatu waktu } \\
\text { tertentu. Sumber: Pribadi dan Sampurno } \\
(2012)\end{array}$ & Posisi kas akhir tahun & Ratio \\
\hline $\begin{array}{l}\text { Total asset } \\
\text { turnover } \\
\left(\mathrm{X}_{6}\right)\end{array}$ & $\begin{array}{l}\text { Merupakan rasio yang digunakan untuk } \\
\text { mengukur perputaran semua aktiva yang } \\
\text { dimiliki perusahaan dan mengukur berapa } \\
\text { jumlah penjualan yang diperoleh dari tiap } \\
\text { rupiah aktiva. } \\
\text { Sumber : Kasmir }(2016: 185)\end{array}$ & $\begin{array}{l}\text { Total asset turn over }= \\
\text { Sales/Total Assets. } \\
\text { Sumber:Sudana } \\
(2015: 22)\end{array}$ & Ratio \\
\hline $\begin{array}{l}\text { Dividend } \\
\text { payout ratio } \\
\text { (Y) }\end{array}$ & $\begin{array}{l}\text { Devidend payout ratio merupakan } \\
\text { kemampuan perusahaan memenuhi seluruh } \\
\text { kewajibannya, peningkatan hutang } \\
\text { mempengaruhi besar kecilnya laba bersih } \\
\text { yang tersedia bagi para pemegang saham. } \\
\text { (Fahmi; 2011) }\end{array}$ & $\begin{array}{l}\mathrm{DPR}=\text { Deviden per } \\
\text { share/earning per share }\end{array}$ & Ratio \\
\hline
\end{tabular}




\section{Teknik analisis data}

Model Analisis data dalam analisis regresi berganda dalam penelitian ini yaitu:

$Y=a+b_{1} X_{1}+b_{2} X_{2}+b_{3} X_{3}+b_{4} X_{4}+b_{5} X_{5}+b_{6} X_{6}+e$

Keterangan :

Y :Dividend payout ratio (DPR)

a :Konstanta

bi :Koefisien regresi

$\mathrm{X}_{1}$ :Debt to equity ratio(DER)

$\mathrm{X}_{2}$ :Return on asset(ROA)

$\mathrm{X}_{3}$ :Firmsize

$\mathrm{X}_{4}$ :Earning pershare

$\mathrm{X}_{5}:$ :Cash position

$\mathrm{X}_{6}$ :Total asset turnover

Se :Standard error

Metode mensyaratkan untuk melakukan uji asumsi klasik guna mendapatkan hasil yang terbaik (Ghozali, 2016). Tujuan pemenuhan asumsi klasik agar variael bebas sebagai estimator atas variabel tidak bias. Dimana pengujian asumsi klasik terdiri atas: Uji normalitas, uji multikolonieritas, uji autokolerasi, dan uji heterokedastisitas (Ghozali, 2016)

\section{HASIL DAN PEMBAHASAN}

\section{Statistik deskriptif}

Jumlah $(\mathrm{N})$ pada Tabel 4 menunjukkan banyaknya jumlah sampel pada peneltian ini yaitu 216 data dari 54 perusahaan sampel dikali 4 tahun periode penelitian (2016-2019).

Tabel 4.Statistik deskriptif

\begin{tabular}{lrrrrr}
\hline & N & \multicolumn{1}{c}{ Minimum } & \multicolumn{1}{c}{ Maximum } & \multicolumn{1}{c}{ Mean } & \multicolumn{1}{c}{ Std. Deviation } \\
\hline DER & 216 &, 083 & 2,909 &, 78484 &, 593004 \\
ROA & 216 &, 001 &, 527 &, 09540 &, 087108 \\
FirmSize & 216 & 24,077 & 33,495 & 29,03253 & 1,823142 \\
EPS & 216 &, 018 & 5654,993 & 321,70994 & 647,426589 \\
CashPosition & 216 & -240748000000000 & 4194250161224,12 & 18992281988859,223 \\
TATO & 216 &, 307 & 2,392 & &, 01146 \\
DPR & 216 &, 002 & 10,843 &, 51391 &, 888085 \\
Valid N & 216 & & & & \\
(listwise) & & & & & \\
\hline
\end{tabular}

Sumber: Data diolah, 2021

DER memiliki nilai minimum sebesar 0,083 yang diperoleh PT. Sidomuncul, Tbk di Tahun 2016 dan nilai maksimum sebesar 2,909 yang diperoleh PT. Unilever Indonesia, Tbk Tahun 2019. DER rata-rata selama 4 tahun sebesar 0,78484.ROA 
memiliki nilai minimum sebesar 0,001 yang diperoleh PT. Lion Metal Works, Tbk di tahun 2019 dan nilai maksimum sebesar 0,527 yang diperoleh PT. Multi Bintang Indonesia, Tbk di tahun 2017. ROA rata-rata selama 4 tahun sebesar 0,09540.

Firm Size nilai minimum sebesar 24,077 yang diperoleh PT. Chandra Asri Petrochemical, Tbk di tahun 2016 dan nilai maksimum sebesar 33,495 yang diperoleh PT. Astra International, Tbk di tahun 2019. Firm Size rata-rata selama 4 tahun sebesar $29,03253$.

EPS memiliki nilai minimum sebesar 0,018 yang diperoleh PT. Chandra Asri Petrochemical, Tbk di tahun 2019 dan nilai maksimum sebesar 5654,993 yang diperoleh PT. Gudang Garam, Tbk di tahun 2019. EPS rata-rata selama 4 tahun sebesar $321,70994$.

Cash Position memiliki nilai min sebesar -Rp 126.576.603.862,- yaitu pada PT. Sekar Laut, Tbk tahun 2018 dengan nilai max sebesar Rp 240.748.000.000.000,- pada PT. Selamat Sempurna, Tbk tahun 2019 dan rata-rata selama 4 tahun sebesar Rp 4.194.250.161.224,-.

Total Asset Turnover nilai minimumnya sebesar 0,307 jatuh pada PT. Semen Baturaja Persero, Tbk di tahun 2017, maksimumnya sebesar 2,392 jatuh pada PT. Unilever Indonesia, Tbk di tahun 2016 dan rata-rata selama 4 tahun sebesar 1,01146.

Dividend Payout Ratio nilai minimumnya 0,002 jatuh pada PT. Unggul Indah Cahaya, Tbk di tahun 2016, maksimumnya sebesar 10,843 jatuh pada PT. Merck, Tbk di tahun 2018 dan rata-rata selama 4 tahun yaitu 0,51391 .

\section{Uji asumsi klasik}

\section{Uji normalitas}

Data penelitian mengalami masalah pada uji normalitasnya sehingga teknik transformasi yang memenuhi persyaratan asumsi klasik yaitu membuang data outlier > 2,5 sebanyak 28 data selanjutnya ditransformasi dengan teknik SQRT. Adapun hasil uji normalitasnya adalah sebagai berikut:

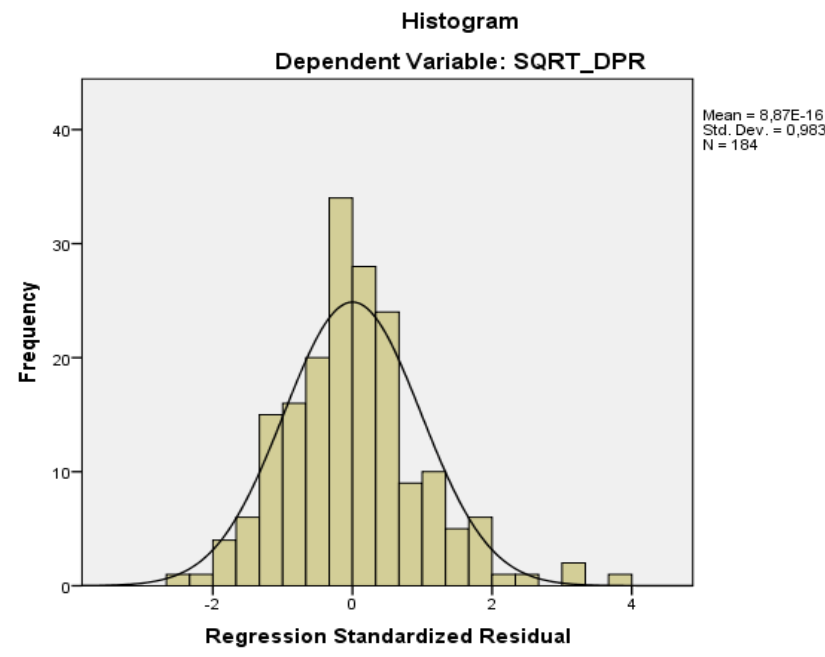

Gambar 2. Uji normalitas

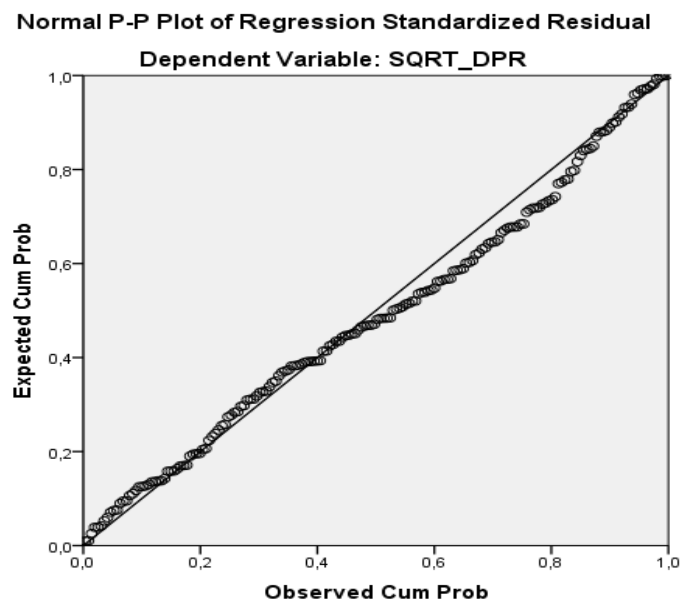

Gambar 3. Uji normalitas P-P Plot

Berdasarkan Gambar 2 histogram menunjukkan setelah transformasi data telah memiliki distribusi normal karena visual grafik berbentuk simetris tidak menceng ke 
kanan atau ke kiri. Selain histogram asumsi normalitas juga dapat dilihat dari grafik PPlot.

Selanjutnya pada Gambar 3. P Plot menunjukkan data memiliki distribusi normal yang dapat dilihat dari plot yang bergerak mengikuti garis diagonal.

Tabel 5. Hasil uji KS

One-sample kolmogorov-smirnov test

\begin{tabular}{llr}
\hline & & $\begin{array}{r}\text { Unstandardized } \\
\text { Residual }\end{array}$ \\
\hline $\mathrm{N}$ & Mean & 184 \\
Normal Parameters & a, &, 0000000 \\
& Std. Deviation &, 23012476 \\
Most Extreme Differences & Absolute &, 068 \\
& Positive &, 068 \\
Kolmogorov-Smirnov Z & Negative &,- 030 \\
Asymp. Sig. (2-tailed) &, 926 \\
a. Test distribution is Normal. &, 358 \\
b. Calculated from data. & \\
Sumber: Data diolah, 2021 &
\end{tabular}

Berdasarkan hasil uji K-S diperoleh nilai signifikan 0,358 > 0,05 maka dapat diambil kesimpulan jika data setelah di transformasi telah memenuhi asumsi normalitas.

\section{Uji multikolineritas}

Uji multikolinearitas merupakan syarat asumsi kedua setelah normalitas. Untuk melihat apakah diantara variabel independen tidak memiliki korelasi maka dapat dilihat nilai tolerance dan VIF.

Tabel 6. Uji multikolinearitas

\begin{tabular}{|c|c|c|c|}
\hline \multicolumn{4}{|c|}{ Coefficients $^{\mathbf{a}}$} \\
\hline \multirow{2}{*}{\multicolumn{2}{|c|}{ Model }} & \multicolumn{2}{|c|}{ Collinearity Statistics } \\
\hline & & Tolerance & VIF \\
\hline \multirow{6}{*}{1} & SQRT_DER & ,754 & 1,326 \\
\hline & SQRT_ROA & 632 & 1,583 \\
\hline & SQRT_FirmSize & ,285 & 3,508 \\
\hline & SQRT_EPS & 672 & 1,489 \\
\hline & SQRT_CashPosition & ,319 & 3,135 \\
\hline & SQRT_TATO & ,791 & 1,265 \\
\hline
\end{tabular}

a. Dependent Variable: SQRT_DPR

Sumber: Data diolah, 2021

Dari hasil pengujianmultikolinearitas menunjukkan variabel independen tidak saling berkorelasi karena nilai tolerance masing-masing variabel bebas telah lebih besar dari 0,10 dan nilai VIF dari masing-masing variabel bebas telah lebih kecil dari 10 .

\section{Uji autokorelasi}

Regresi yang baik harus memenuhi asumsi ketiga yaitu tidak terjadi korelasi yang hasil pengujiannya dapat dilihat pada Tabel 7 berikut : 
Tabel 7. Uji autokorelasi

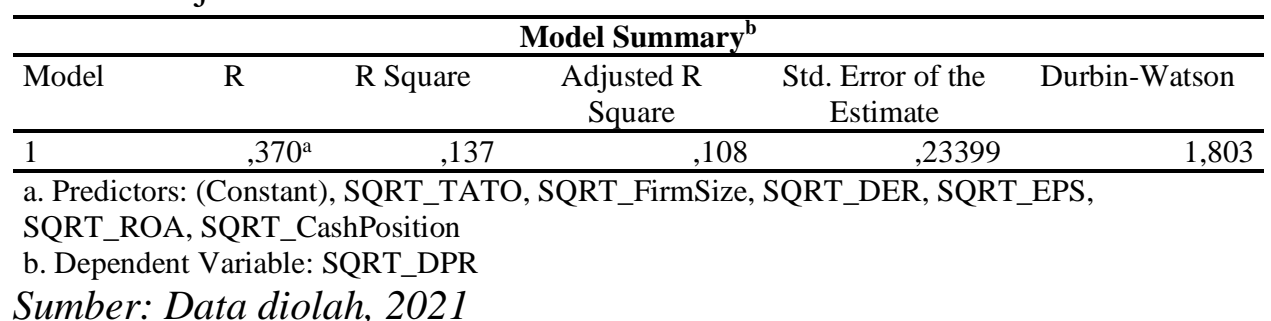

Dengan melihat pedoman pada tabel Durbin Watson untuk $\mathrm{k}=6$ dan $\mathrm{n}=184$ maka :
$\mathrm{dL}=1,6919$
$4-\mathrm{dL}=2,3081$
$\mathrm{dU}=1,8264$
$4-\mathrm{dU}=2,1736$

Sehingga hasil uji Durbin Watson memenuhi kriteria kelima yaitu dU $<\mathrm{d}<4-$ dU atau $1,8264<1,803<2,1736$ yang artinya tidak ada autokorelasi positif atau negatif pada penelitian ini.

\section{Uji heteroskedastisitas}

Uji heteroskedastisitas pada penelitian ini menggunakan metode grafik dan statistik, dimana metode statistik yang dipilih menggunakan uji Glejser.

$$
\text { Scatterplot }
$$

Dependent Variable: SQRT_DPR

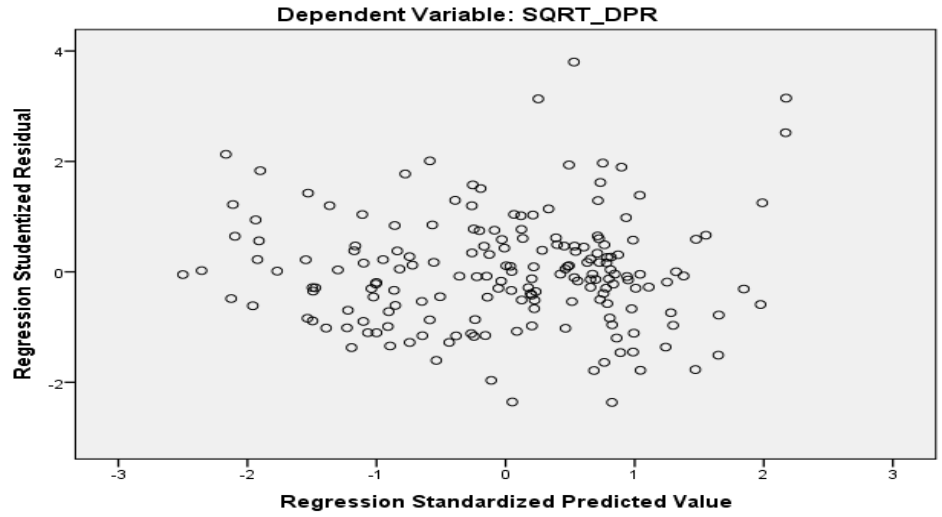

Gambar 4. Uji heteroskedastisitas Scatterplot

Dari hasil uji pada Gambar 4 scatterplot data menunjukkan plot telah tersebar secara acak sehingga data pada penelitian ini telah memenuhi syarat uji asumsi klasik karena tidak terjadi heteroskedastisitas.

Tabel 8. Uji Gletser

\begin{tabular}{|c|c|c|c|c|c|c|}
\hline \multicolumn{7}{|c|}{ Coefficients $^{\mathrm{a}}$} \\
\hline & \multirow[t]{2}{*}{ Model } & \multicolumn{2}{|c|}{$\begin{array}{l}\text { Unstandardized } \\
\text { Coefficients }\end{array}$} & \multirow{2}{*}{$\begin{array}{c}\begin{array}{c}\text { Standardized } \\
\text { Coefficients }\end{array} \\
\text { Beta }\end{array}$} & \multirow[t]{2}{*}{$\mathbf{t}$} & \multirow[t]{2}{*}{ Sig. } \\
\hline & & B & Std. Error & & & \\
\hline \multirow{7}{*}{1} & (Constant) & , 185 & ,634 & & ,291 & ,771 \\
\hline & SQRT_DER &,- 058 & 045 &,- 109 & $-1,291$ & , 198 \\
\hline & SQRT_ROA & 017 &, 157 &, 010 & , 111 & ,912 \\
\hline & SQRT_FirmSize &, 022 & ,123 & ,025 & , 181 & 857 \\
\hline & SQRT_EPS & ,003 & ,001 &, 151 & 1,690 & ,093 \\
\hline & SQRT_CashPosition & $-2,269 \mathrm{E}-008$ &, 000 &,- 159 & $-1,225$ & ,222 \\
\hline & SQRT_TATO &,- 105 &, 067 &,- 130 & $-1,571$ &, 118 \\
\hline
\end{tabular}

a. Dependent Variable: ABSUT

Sumber: Data diolah, 2021 
Dari hasil uji Gletser, menunjukkan data pada penelitian ini tidak terjadi heteroskedastisitas karena nilai signifikan dari enam variabel bebas memiliki masingmasing nilai signifikan lebih besar dari 0,05.

Tabel 9. Uji regresi linear berganda

\begin{tabular}{llrrr}
\hline \multirow{2}{*}{ Model } & \multicolumn{2}{c}{ Unstandardized Coefficients } & \multicolumn{2}{c}{$\begin{array}{c}\text { Standardized } \\
\text { Coefficients }\end{array}$} \\
\cline { 2 - 5 } & B & & Std. Error & Beta \\
\hline (Constant) &, 468 &, 982 & \\
SQRT_DER &,- 345 &, 070 &,- 396 \\
& SQRT_ROA &,- 247 &, 243 &,- 089 \\
1 & SQRT_FirmSize &, 089 &, 191 &, 061 \\
& SQRT_EPS &,- 001 &, 002 &,- 027 \\
& SQRT_CashPosition &, 00000003 &, 000 &, 111 \\
SQRT_TATO &,- 047 &, 103 &,- 036 \\
\hline
\end{tabular}

a. Dependent Variable: SQRT_DPR

Sumber: Data diolah, 2021

Persamaan regresi berganda pada penelitian ini yaitu :

$\mathbf{Y}=\mathbf{a}+\mathbf{b}_{1} \mathbf{X}_{1}$

\section{DPR = 0,468 - 0,345 DER - 0,247 ROA + 0,089 FirmSize - 0,001 EPS + 0,00000003 Cash Position- 0,047 TATO}

Dari persamaan regresi berganda tersebut dapat dijelaskan sebagai berikut :

1. Konstanta (a) sebesar 0,468 artinya jika variabel bebas konstan atau bernilai 0 maka dividend payout ratio akan bernilai sebesar 0,468.

2. $b_{1} X_{1}$ sebesar $-0,346$ artinya setiap peningkatanDER sebanyak 1 satuan akan menyebabkan dividend payout ratio menurun sebesar 0,346.

3. $\mathrm{b}_{2} \mathrm{X}_{2}$ sebesar $-0,247$ artinya setiappeningkatan ROA sebanyak 1 satuan akan menyebabkan dividend payout ratio menurun sebesar 0,247.

4. $\mathrm{b}_{3} \mathrm{X}_{3}$ sebesar 0,089 artinya setiap peningkatan Firm Size sebanyak1 satuan akan menyebabkan dividend payout ratio meningkat sebesar 0,089 .

5. $\mathrm{b}_{4} \mathrm{X}_{4}$ sebesar $-0,001$ artinya setiap peningkatan EPS sebanyak 1 satuan akan menyebabkan dividend payout ratio menurun sebesar -0,001.

6. b4X5 sebesar 0,00000003 artinya setiap peningkatan Cash Position sebanyak 1 satuan akan menyebabkan dividend payout ratio meningkat sebesar 0,00000003.

7. b6x6 sebesar -0,047 artinya setiap peningkatan total asset turnover sebanyak 1 satuan akan menyebabkan dividend payout ratio menurun sebesar 0,047.

\section{Uji hipotesis}

\section{Koefisi en determinasi}

Besarnya pengaruh dari variabel independen terhadap variabel dependen dilihat dari angkaAdjusted $R$ Squareyang menunjukkan sebesar 0,108 yang berartisebesar 10,8\% dari variasi Dividend Payout Ratio yang dapat dijelaskan oleh DER, ROA, Firm Size, EPS, Cash Position dan Total Asset Turnover dimana sisanya sebesar 89,2\% dipengaruhi oleh faktor lainnya yaitu Growth Opportunity, Ownership, Current Ratio dan lain-lain. 
Tabel 10. Uji koefisien determinasi

\begin{tabular}{|c|c|c|c|c|}
\hline \multicolumn{5}{|c|}{ Model Summary } \\
\hline Model & $\mathrm{R}$ & R Square & Adjusted R Square & $\begin{array}{l}\text { Std. Error of the } \\
\text { Estimate }\end{array}$ \\
\hline 1 &, $370^{\mathrm{a}}$ & 137 & 108 & 23399 \\
\hline $\begin{array}{l}\text { a. Pred } \\
\text { SQRT }\end{array}$ & $\begin{array}{l}\text { Consta } \\
\text { QRT_l }\end{array}$ & $\begin{array}{l}\text {, SQRT_T } \\
\text { A, SQRT }\end{array}$ & $\begin{array}{l}\text { TO, SQRT_FirmSize } \\
\text { ashPosition }\end{array}$ & T_DER, \\
\hline
\end{tabular}

\section{Uji F}

Besarnya nilai $F$ tabel untuk df $1=6$ dan df $2=177$ yaitu sebesar 2,15. Dengan melihat hasil uji $\mathrm{F}$ diperoleh nilai $\mathrm{F}$ hitung $(4,692)>\mathrm{F}$ tabel 2,15 dan nilai signifikan $0,000<0,05$ maka Ha diterima yang berarti DER, ROA, Firm Size, EPS, Cash Position dan Total Asset Turnover secara simultan berpengaruh signifikan terhadap perusahaan manufaktur tahun 2016-2019.

Tabel 11. Uji F

\begin{tabular}{llrrrrr}
\hline \multicolumn{2}{l}{ Model } & \multicolumn{1}{c}{$\begin{array}{c}\text { Sum of } \\
\text { Squares }\end{array}$} & Df & Mean Square & F & \multicolumn{1}{l}{ Sig. } \\
\hline \multirow{3}{*}{1} & Regression & 1,541 & 6 &, 257 & 4,692 &, $000^{\mathrm{b}}$ \\
& Residual & 9,691 & 177 &, 055 & & \\
& Total & 11,233 & 183 & & & \\
\hline
\end{tabular}

a. Dependent Variable: SQRT_DPR

b. Predictors: (Constant), SQRT_TATO, SQRT_FirmSize, SQRT_DER, SQRT_EPS, SQRT_ROA, SQRT_CashPosition

Sumber: Data diolah, 2021

\section{Uji t}

Uji ini disebut uji secara parsial yang bertujuan untuk mengetahui apakah terdapat pengaruh satu variabel bebas terhadap variabel terikatnya atau tidak.

Tabel 12. Uji t

\begin{tabular}{llrc}
\hline \multicolumn{1}{c}{ Model } & \multicolumn{1}{c}{ t } & Sig. \\
\hline \multirow{2}{*}{1 (Constant) } &, 477 &, 634 \\
& SQRT_DER & $-4,923$ &, 000 \\
& SQRT_ROA & $-1,018$ &, 310 \\
& SQRT_FirmSize &, 466 &, 642 \\
& SQRT_EPS &,- 312 &, 755 \\
& SQRT_CashPosition &, 895 &, 372 \\
& SQRT_TATO &,- 459 &, 647 \\
\hline
\end{tabular}

a. Dependent Variable: SQRT_DPR

Sumber: Data diolah, 2021

Besarnya t Tabel 12 pada alpha 0,05 (twotailed), df 177 adalah 1,97346. Dengan membandingkan hasil uji secara parsial tersebut dengan besarnya t tabel maka: pada variabel DER yaitu nilai $-\mathrm{t}_{\text {hitung }}<-\mathrm{t}_{\text {tabel }}$ atau $-4,923<-1,97346$ dan nilai signifikan $0,000<$ 0,05 maka berartiHa dterima berarti terdapatpengaruh DER secara negatif signifikan terhadap Dividend Payout Ratio perusahaan manufaktur tahun 2016-2019. 
Pada variabel ROA yaitu nilai $-\mathrm{t}_{\text {hitung }}>-\mathrm{t}_{\text {tabel }}$ atau $-1,018>-1,97346$ dan nilai signifikan 0,310 > 0,05 maka Ho diterima artinya tidak terdapatpengaruh ROA terhadap Dividend Payout Ratio perusahaan manufaktur tahun 2016-2019.

Pada variabel Firm Size yaitu nilai $t_{\text {hitung }}<\mathrm{t}_{\text {tabel }}$ atau0,466<1,97346 dan nilai signifikan 0,642>0,05 maka Ho diterima artinyatidak terdapat pengaruh Firm Sizeterhadap Dividend Payout Ratio perusahaan manufaktur tahun 2016-2019.

Pada variabel EPS yaitu nilai - $t_{\text {hitung }}>-t_{\text {tabel }}$ atau $-0,312>-1,97346$ dan nilai signifikan 0,755 > 0,05 maka Ho diterima artinya tidak terdapatpengaruh EPS terhadap Dividend Payout Ratio perusahaan manufaktur tahun 2016-2019.

Pada variabel Cash Position yaitu nilai $t_{\text {hitung }}<t_{\text {tabel }}$ atau0,895<1,97346 dan nilai signifikan 0,372>0,05 maka Ho diterima artinyatidak terdapat pengaruh Cash Positionterhadap Dividend Payout Ratio perusahaan manufaktur tahun 2016-2019.

Pada variabel Total Asset Turnover yaitu nilai - $t_{\text {hitung }}>-t_{\text {tabel }}$ atau $-0,459>-1,97346$ dan nilai signifikan 0,647>0,05 maka Ho diterima artinya tidak terdapatpengaruh Total Asset Turnoverterhadap Dividend Payout Ratio perusahaan manufaktur tahun 20162019.

\section{DER terhadap DPR}

Hasil penelitian terbukti jikaDERdapat mempengaruhi dividend payout ratio perusahaan manufaktur. Begitu juga dengan hasil penelitian yang diperoleh Akmal, Zainudin dan Yulianti (2016) yaitu DER berpengaruh secara negatif signifikan pada dividend payout ratio.

Perusahaan yang memiliki rasio hutang yang tinggi cenderung mengutamakan pembayaran hutangnya daripada pembagian dividennya kepada pemegang sahamnya, sehingga jika semakin tinggi tingkat hutang yang dimiliki oleh suatu perusahaan maka mengurangi pembagian dividennya.

\section{ROA terhadap DPR}

Hasil penelitian tidak dapat membuktikan pengaruh ROA terhadap rasio pembagian dividen perusahaan manufaktur. Begitu juga dengan hasil penelitian yang diperoleh Swastyastu, dkk 2014 yaitu ROA tidak mempengaruhi DPR.

Berdasarkan teori yang ada pembagian dividen dibagikan jika perusahaan mendapatkan laba / keuntungan, namun tidak pastinya kondisi penjualan membuat perusahaan harus menahan pembagian dividennya sehingga banyak perusahaan yang mendapatkan laba namun enggan membagikan dividennya kepada pemegang sahamnya.

\section{Firm size terhadap DPR}

Hasil penelitian tidak dapat membuktikan pengaruhsize perusahaan terhadap rasio pembagian dividen perusahaan manufaktur. begitu juga dengan hasil penelitian yang diperoleh Swastyastu, dkk 2014 size perusahaan tidak mempengaruhi dividend payout rationya.

Berdasarkan hasil penelitian ini besar kecilnya perusahaan tidak mempengaruhi pembagian dividennya, dikarenakan dividen merupakan pembagian keuntungan yang dinantikan oleh pemegang sahamnya dan sudah seharusnya perusahaan membagikan dividennya jika mendapatkan laba sehingga baik besarnya pembagian dividen pada perusahaan kecil maupun perusahaan besar tidak berpengaruh sejauh perusahaan mampu mendapatkan laba dan menjaga keseimbangan arus kasnya. 


\section{EPS terhadap DPR}

Hasil penelitian ini tidak dapat membuktikan adanya pengaruh EPS terhadap rasio pembagian dividen perusahaan manufaktur. Begitu juga dengan hasil penelitian yang diperoleh Sarmento dan Dana (2016) yaitu EPS tidak mempengaruhi DPR secara signifikan.

Hasil penelitian ini menunjukkan jika EPS tidak mempengaruhi pembagian dividennya, dikarenakan tidak stabilnya laba bersih perusahaan mengakibatkan perusahaan harus menunda pembagian dividennya sehingga terkadang meskipun perusahaan mendapatkan laba perusahaan tidak akan mengumumkan pembagian dividen.

\section{Cash position terhadap DPR}

Hasil penelitian ini tidak dapat membuktikan pengaruh Cash Position terhadap rasio pembagian dividen perusahaan manufaktur. begitu juga dengan hasil penelitiannya Tiurma dan Widjaja (2019) yang menunjukkan bahwa Cash Position tidak mempengaruhi DPR.

Berdasarkan hasil penelitian ini menunjukkan bahwa pembagian dividen hanya akan dilakukan oleh perusahaan jika memiliki posisi kas yang cukup. Tidak berpengaruhnya posisi kas terhadap DPR pada penelitian ini dikarenakan cadangan kas yang ditahan untuk pembagian dividen tidak mencukupi untuk pembagian dividennya.

\section{Total asset turnover terhadap DPR}

Hasil penelitian ini tidak dapat membuktikan pengaruh total asset turnover terhadap rasio pembagian dividen perusahaan manufaktur. Begitu juga dengan hasil penelitian yang diperoleh Angeline (2019) yang menunjukkan bahwa total asset turnover tidak berpengaruh terhadap DPR.

Tidak berpengaruhnya total asset turnover dikarenakan aset yang dimiliki oleh perusahaan sebagian besar dibiayai oleh hutang menyebabkan tidak mempengaruhi pembagian dividennya dimana jika perusahaan dapat menghasilkan keuntungan maka perusahaan akan melakukan pembayaran hutangnya kepada pihak ketiga terlebih dahulu.

\section{KESIMPULAN DAN SARAN}

\section{Kesimpulan}

Setelah menganalisis data maka simpulan dari peneliti terkait hasil penelitian ini yaitu secara parsial DER dapat mempengaruhi kebijakan DPRnya perusahaan manufaktur untuk tahun 2016-2019. Secara parsial ROA, firm size, EPS, cash position dan total asset turnover tidak dapat mempengaruhi kebijakan DPRnya perusahaan manufaktur untuk tahun 2016-2019.

Secara bersamaan DER, ROA, Firm Size, EPS, cash position dan total asset turnover mempengaruhi kebijakan DPRnya perusahaan manufaktur untuk tahun 20162019.Besarnya pengaruh variasi variabel terikat yang dapat dijelaskan oleh enam variabel independen dapat dilihat dari nilai adjusted $R$ Square sebesar 10,8\% dimana sisanya $89,2 \%$ dipengaruhi oleh variabel lainnya.

\section{Saran}

Peneliti memberikan saran bagi pihak yang berkepentingan yaituBagi peneliti lainnya disarankan untuk menambahkan variabel bebas lainnya karena variabel yang 
terbukti mempengaruhi kebijakan DPR-nya perusahaan manufaktur hanya DER, variabel lain yang dapat digunakan misalnya growth opportunity, ownership, current ratio dan lain-lain serta bagi perusahaan manufaktur sebaiknya menetapkan porsi pembagian dividen yang stabil, dengan demikian nilai perusahaan akan meningkat yang akan berdampak pada peningkatkan kinerja finansialnya.

\section{DAFTAR PUSTAKA}

Abdullah, H., Soedjatmiko, \& Hartati, A. (2016). Pengaruh EPS, DER, ROA dan ROE terhadap harga saham pada perusahaan tambang yang terdaftar di BEI untuk Periode 2011-2013. Dinamika Ekonomi Jurnal Ekonomi dan Bisnis, 9(1), 1-20

Akmal, A., Zainuddin, Z., \& Yulianti, R. (2016). Pengaruh return on asset, sales growth, firm size dan debt to equity ratio terhadap pembayaran dividen pada perusahaan manufaktur sub sektor perusahaan makanan dan minuman yang terdaftar di Bursa Efek Indonesia Periode 2010-2014. Jurnal Ekonomi Manajemen dan Akuntansi (JEMSI), 2(2), 24-36.

Alipudin, A. (2016). Pengaruh EPS, ROE, ROA dan DER terhadap harga saham pada perusahaan sub sektor semen yang terdaftar di BEI. JIAFE (Jurnal Ilmiah Akuntansi Fakultas Ekonomi), 2(1), 1-22.

Angeline, V. (2019). Analisis pengaruh return on asset, current ratio, debt to equity dan total asset turnover terhadap kebijakan dividen pada perusahaan food and beverages yang terdaftar di BEI pada Periode 2015-2017. Jurnal Bisnis dan Ekonomi, 1(1), 53-67.

Atmoko, Y., Defung, F., \& Tricahyadinata, I. (2018). Pengaruh return on assets, debt to equity ratio, dan firm size terhadap dividend payout ratio. Jurnal Ekonomi dan Manajemen, 14(2), 103-109.

Chasanah, A. N. (2008). Faktor-faktor yang mempengaruhi dividend payout ratio (DPR) pada perusahaan yang listed di Bursa Efek Indonesia. Tesis. Universitas Dipenogoro: Semarang.

Erari, A. (2014). Analisis pengaruh current ratio, debt to equity ratio, dan return on asset terhadap return saham pada perusahaan pertambangan di Bursa Efek Indonesia. Jurnal Manajemen Bisnis Universitas Muhammadiyah Yogyakarta, 5(2), 175-191.

Fahmi. (2011). Analisis laporan keuangan. Edisi ke-10. Alfabeta: Lampulo

Fitriah, \& Sudirjo, F. (2016). Pengaruh analisis rasio keuangan, rasio pasar dan kebijakan deviden terhadap harga saham. Jurnal Ilmiah UNTAG Semarang, $5(2), 1-16$.

Fitriati, I.R. (2018). Analisis pengaruh return on equity, firm size, current ratio dan institusional ownership terhadap dividend payout ratio dengan debt to equity ratio sebagai variabel intervening, Jurnal Riset Ekonomi dan Bisnis, 11(3), 174190.

Ghozali, I. (2016). Aplikasi analisis multivariate dengan program IBM SPSS 23. Edisi 8. Cetakan ke-8. Badan Universitas Diponegoro: Semarang

Hanif, M., \& Bustaman. (2017). Pengaruh debt to equity ratio, return on asset, firm size dan earning pe share terhadap dividend payout ratio. Jurnal Ilmiah Mahasiswa Ekonomi Akuntansi, 2(1), 73-81.

Harmono. 2015. Manajemen keuangan berbasis balances scorecard pendekatan teori, kasus dan riset bisnis. Bumi Aksara: Jakarta

Ismiyanti, F., \& Mahadwartha, P. A. (2005). Uji faktor-faktor pembeda kebijakan 
dividen: analisis diskriminan. Journal of Management and Business, 4(1), 3047.

Janifairus, J. B., Hidayat, R., Husaini, A., (2013). Pengaruh return on asset, debt to equity ratio, assets growth, dan cash ratio terhadap dividend pay out ratio. Jurnal Administrasi Bisnis, 1(1), 161-169.

Mulyawan, Setia. 2015. Manajemen keuangan. CV. Pustaka Setia: Bandung.

Sarmento, J. D. C., \& Dana, M. (2016). Pengaruh return on equity, current ratio, dan earning per share terhadap kebijakan dividen pada perusahaan keuangan. EJurnal Manajemen Universitas Udayana, 5(7), 4224-4252.

Swastyastu, Made Wiradharma, dkk. 2014. Analisis faktor-faktor yang mempengaruhi kebijakan dividend payout ratio yang terdaftar di bursa efek indonesia (BEI). $e$ Journal S1 Ak Universitas Pendidikan Ganesha Jurusan Akuntansi Program S1, 2(1), 1-12.

Tiurma, R. C. M., \& Widjaja, I. (2020). Analisis pengaruh current ratio, return on assets, debt equity ratio, dan cash position terhadap dividen payout ratio pada perusahaan manufaktur industri barang konsumsi yang terdaftar di Bursa Efek Indonesia Selama Periode 2015-2017. Jurnal Manajemen Bisnis dan Kewirausahaan, 4(4), 168-172.

Wahyuni, S.F. dan Hafiz, M.S. (2018). Pengaruh CR, DER dan ROA terhadap DPR pada perusahaan manufaktur di BEI. Jurnal Ekonomi \& Ekonomi Syariah, 1(2), $25-42$. 